\title{
Mobile banking usage and gamification: the moderating effect of generational cohorts
}

\author{
Gentjan Çera, ${ }^{1,2}$ Ina Pagria, ${ }^{2}$ Khurram Ajaz Khan, ${ }^{1}$ Lindita Muaremi ${ }^{3}$ \\ ${ }^{1}$ Tomas Bata University in Zlin, Faculty of Management and Economics, Czech Republic, cera@utb.cz, \\ khan@utb.cz \\ ${ }^{2}$ Agricultural University of Tirana, Faculty of Economics and Agribusiness, Albania, ipagria@ubt.edu.al \\ ${ }^{3}$ State University of Tetova, Faculty of Economics, North Macedonia \\ lindita.muaremi@unite.edu.mk
}

\begin{abstract}
The extended unified theory of acceptance and use of technology (UTAUT2) model to gain insight regarding mobile banking (m-banking) usage has been developed. By combining three perspectives, UTAUT2, gamification and generational cohort theory, this study seeks to investigate the factors which impact $\mathrm{m}$-banking usage and to examine the moderating effect of generations $\mathrm{Y}$ and $\mathrm{Z}$ into the relationship between gamification and intention to use m-banking. The adopted model was tested in a quantitative study by employing partial least square structural equation modelling. To carry out the data analyse 380 valid questionnaire has been proceed. Within the study are provided scientific evidences concerning the UTAUT2 model and gamification elements. The results revealed that the age significantly moderate the relationship between gamification and behavioural intention. Compare to generation $\mathrm{Z}$, individuals inborn before 1996 (generation Y) scored lower on gamification, manifest lower intention to use m-banking, whereas m-banking users score higher gamification indicated higher behavioural intention. Besides identifying the determinants of m-banking usage, this study notably reveal the importance of generational cohorts as moderators effect of gamification on m-banking behavioural intention.
\end{abstract}

\section{Keywords}

Mobile banking, UTAUT2, gamification, transition country, Generation Y and Z, PSL-SEM

\section{Introduction}

Emerging communication technologies have been evolving in the world over the last few decades. Internet based applications and wireless phones are empowering continuously individuals to execute financial or non-financial transactions at any corner of the world just from a finger touch. Peeping into the past, one of the first commercial applications of the mobile internet was mobile banking, which came out as an innovative extension of telephone banking and online banking (Barnes \& Corbitt, 2003). Since the 1990s banking system in Europe has stretched rapidly much faster than many other banking systems (Langfield \& Pagano, 2015). Therefore, this simultaneous expansion of banking system, internet, and wireless mobile, gave a strong tool in the hands of the banking services providers to take the banking services in the pockets of the consumers and empower them to access from anywhere at any time (Laukkanen \& Pasanen, 2008) and this easiness delight individuals.

Mobile banking services are about complete accessibility to banking services and easy transactions from bank accounts, instalment payments, fund transfer and other related banking services (Al-Jabri \& Sohail, 2012). According to Shaikh, Karjaluoto, and Chinje (2015a). M-banking services just need an electronic device such as smartphones or tablets, to execute financial and non-financial transactions. This easiness of service usage is behind its acceptance and adaptability around the world. This explains itself why mbanking is expanding rapidly, bankers want to grab this as an opportunity to improve their competitiveness, 
expand their banking services, and to enhance customer loyalty and satisfaction (Alalwan, Dwivedi, Rana, Lal, \& Williams, 2015). M-banking can help in the customer's base expansion, operational efficiency, costeffective, and can enhance revenue, and for consumers, it facilitates easy, cost-effective and anywhere banking (Al-Jabri \& Sohail, 2012).

Banking services are rapidly expanding, including offering the service remotely (Langfield \& Pagano, 2015). Therefore, it is predicted that m-banking will continue gaining its popularity, particularly among banks as it has potential to upsurge their market share (Vella, Wallström, \& Farshid, 2017). Based on the same reasons, expansion of electronic devices, applications and internet are the causes behind the advent of gamification also, which are consist of group of activities which brings fun, excitement, motivation and joyful experience in usage, as well as an improved gamification stage, can help service providers to learn about their consumers which can be very helpful to design their online experience grounded on the users activities and liking (Zichermann \& Cunningham, 2011). Game-based applications are useful in improving learning and performances (Galetta, 2013). Therefore, it can be assumed that gamification might subsidize to improve m-banking usage.

The whole structure of this system is based on four aspects, human behaviour, banking application, internet, and mobile phone. Continuous improvement in communication technologies, are making software (application and internet) and hardware (electronic device) easy and smooth to use, and the only unrelated, much studied and most dynamic aspect is to understand human behaviour. Therefore, it has to be studied separately on how and what influences consumer behaviour, what drives users' behaviour, and how it can be improved to enhance m-banking adaptability and make it more user-friendly. Therefore, service providers and researchers are continuously trying to understand the factors affecting behaviour intention and usage behaviour. Specifically, the region where the present study is conducted i.e. Albania a country in the transition phase.

Looking into the few facts regarding communication technology expansion and acceptance, along with financial services limitations in Albania. Still, more than ninety percent of the transaction witness cash transaction and a big chunk of the population does not have a bank account. Technological advancement through electronic and m-banking can be useful to remove cash and paper-based transactions and can reduce the cost significantly and can help banking services expansion in Albania. Moreover, initiatives on access and usage will complement the other initiatives such as to enhance financial literacy among Albanians (Bank of Albania, 2018). But the studies on m-banking usage and acceptance in the context of a transition country like Albania is still limited and emerging studies can contribute theoretically for its practical implication and improvement. Apparently, this is one of the reasons to conduct this study in the premises of Albania. Recently, considerable progress has been observed regarding the number of home-banking transactions amplified substantially during 2018 (Bank of Albania, 2019) and it an obvious motivation of study. To sum up, all indications of the fast development trend of technology acceptance and usage in Albania, m-banking seems a burgeoning area to be researched and recommend.

In nutshell, the present study espoused the UTAUT (Unified Theory of Acceptance and Use of Technology) advanced by Venkatesh et al. (2003) and the extended UTAUT2 by Venkatesh, Thong, and Xu (2012). Based on these models, the current study assumes that this extended UTAUT2 model can be useful to explain how Albanian consumers embracing the mobile banking because UTAUT has been considered the most well-known and comprehensive model related with communication technology acceptance (Park, Yang, \& Lehto, 2007). Later, Baptista and Oliveira (2017) studied the combined effect of gamification first time with UTAUT2 theory in the construct to determine the possible impact of the application of game design techniques and game mechanics in the acceptance of m-banking services and found some interesting results. Motivated by the results, the present study covered a further step to assess the relationship between gamification and behavioural intention, identify the generational differences to bring out clearly who and how accepts m-banking. This can help marketers and law-makers to understand and serve specifically Albanian consumers better as well as to generalize it to similar economies. 
The present study is motivated by the discussed model and emerging factors, investigate the further impact of gamification on behavioural intention and the influence of generational difference (Gen $\mathrm{Y}$ and $\mathrm{Z}$ ) on the relationship of gamification and behavioural intention. The present study has identified the key variables such as performance expectancy (PE), effort expectancy (EE), social influence (SI), facilitating conditions (FC), habit (HB), hedonic motivation (HM) on behavioural intention (BI), use behaviour (UB), intention to recommend (IR) and gamification (GM) and a moderator, generation cohort (Gen Y and Z) using the extended UTAUT2 model given by Venkatesh et al. (2012), to investigate the significant factors influence m-banking acceptance and usage under the chosen theory in the context of Albanian consumers' m-banking adaptability and acceptance.

To the best of the authors' knowledge, no other study has covered gamification extensively, how gamification can affect behavioural intention, and comparison of the relationship between gamification and behavioural intention between generation $\mathrm{Y}$ and $\mathrm{Z}$, which represent the core originality of the present study. From the managerial point of view, the moderating effect of generational cohorts into the relationship between GM and BI provides useful insights. The study offers an extended model based on the UTAUT2 of Venkatesh et al. (2012). The adoption of this framework would add substantially to the literature, and the outcome will contribute towards practical implication. The necessity to understand and investigate the factors which affect BI, UB, IR, and GM in the context of a transition country motivated to conduct this research. Hence, this study seeks to investigate the effect of augmented constructs of UTAUT2 and gamification on the intention to use m-banking in the context of a post-communist transition country Albania.

\section{Theoretical background}

The theoretical underpinning of the current research is built on three perspectives: UTAUT2 (Venkatesh et al., 2012), gamification (Kim \& Lee, 2015) and generational cohort theory (Inglehart, 2015). The UTAUT model (Venkatesh et al., 2003) was established based on eight prominent and preceding theories: the theory of reasoned action (Fishbein \& Ajzen, 1975), the technology acceptance model (Davis, 1989), the motivational model (Davis, Bagozzi, \& Warshaw, 1992), the theory of planned behaviour (Ajzen, 1991), the personal computing utilization model (Thompson, Higgins, \& Howell, 1991), the innovation diffusion theory (Rogers, 1995), the social cognitive theory (Compeau \& Higgins, 1995) and the integrated model of technology acceptance and planned behaviour (Taylor \& Todd, 1995). On the other hand, Zichermann and Cunningham (2011) claim that integrating game mechanics into a consumer-facing website or mobile application create a fun-filled and captivating environment for consumers, attract them to visit again and again. Later, other researchers also considered this in their framework and gave meaningful results (Baptista \& Oliveira, 2017; Galetta, 2013; Kim \& Lee, 2015; W. K. Tan, 2018). Thus, the present study applied gamification to examine behavioral intentions. Moreover, the generational cohort theory formulated back in 1977 (Inglehart, 2015) advocates that individuals can be grouped based on their birth years, because it has been found that individuals belonging to a certain generational cohort manifesting common beliefs and attitudes (Meriac, Woehr, \& Banister, 2010). Scholars have considered segmenting the population by generation cohort more efficient that grouping by age (Lissitsa \& Kol, 2016; Parment, 2013). Therefore, the present study will combine these concepts to draw the consumers' behavioral intentions, user behavior and intentions to recommend considering specifically the role of gamification and generational cohorts.

The current research further developed its hypotheses in five blocks with the explanation of each variable how they are related to the dependent variable: (i) factors which influence UB (BI, FC and HB); (ii) factors affecting BI (PE, EE, SI, FC, HB, HM, and gamification); (iii) linking SI, FC, HB, and HM to gamification Fourth, how the generation cohort affects the relationship between gamification and behavioural intention (BI), and Fifth, how user behaviour (UB) affects the intention to recommend (IR). 


\section{Hypotheses development}

The first block of hypotheses deals with the factors affecting user behaviour (UB). Based on UTAUT2, BI, FC, and HB have an imperative role in predicting continuous use of the technology. Moreover, other researchers also applied this in mobile banking studies and found relevant findings (Baptista \& Oliveira, 2017). Looking into the relationship between BI, FC, HB, and UB, the existing literature reveals a strong relationship between the variables, which provide a strong platform to examine the impact on user behaviour. Looking into the meaning of BI, Ajzen (1991) and Fishbein and Ajzen (1975), explained intentions are about how much effort and hard work an individual is putting to achieve the desired behaviour. Intentions are supposed to apprehend the factors which motivate an individual to perform a desirable behaviour. Therefore, it is on the willingness of an individual's intention whether he or she wants to perform a particular behaviour or not. The stronger the intention for expected behaviour, the higher the chances of its achievement. Therefore, it supports that intentions affect behaviour.

Similarly, FC is about providing a supportive set of conditions, such as online seminars or samples, examples and demonstrations, which are helpful to increase the chances of $\mathrm{m}$-banking acceptance (Baptista \& Oliveira, 2017). Another factor is HB, which is elucidated in the context of information system as to what extent people tend to behave automatically because of learning. It reflects that it is about regular and automaticity and it is essential to understand habit to improve the use of technology (Limayem, Hirt, \& Cheung, 2007). A number of studies found that BI positively affects UB (Bhatiasevi, 2016). The studies from different regions reveal strongly that $\mathrm{BI}, \mathrm{FC}$, and $\mathrm{HB}$ have a major influence on UB (Ameen, Willis, \& Hussain Shah, 2018; Baabdullah, Alalwan, Rana, Kizgin, \& Patil, 2019; Baptista \& Oliveira, 2017; Kwateng, Atiemo, \& Appiah, 2019). Therefore, the following hypotheses have been framed:

H1: UB is positively affected by BI (H1a), FC (H1b), and HB (H1c).

The second block of hypotheses is framed to test the factors affecting BI. Venkatesh et al. (2003) explain $\mathrm{PE}$ as the degree to which a person believes that using the system can support to attain the improvements in job performance, it is about perceived usefulness. Similarly, regarding m-banking, researchers found that users perceived that using m-banking can change the nature of banking, navigation patterns, the number of site visits, and the number of transactions executed, will affect the overall usage pattern because of fast, convenient and service effectiveness (Engotoit, Kituyi, \& Moya, 2016; Naicker \& Van Der Merwe, 2018; Zhou, Lu, \& Wang, 2010). On the other hand, EE is about the degree of easiness attached to the system (Venkatesh et al., 2003). It is assumed that easiness helps users to adopt the system easily, sometimes it can be a reason behind the system acceptance or adoption failure, similarly, the same is the case with m-banking. Hence, it is relevant to related EE with $\mathrm{m}$-banking usage. Usefulness and easiness of usage positively affect BI (Ameen et al., 2018; Moazenzadeh \& Hamidi, 2018; Thongsri, Shen, Bao, \& Alharbi, 2018). Studies also indicate that $\mathrm{PE}$ and $\mathrm{EE}$ have a positive effect on the intention to use mobile devices/services or behavioural intention (Carlsson, Carlsson, Hyvönen, Puhakainen, \& Walden, 2006; Rahi \& Abd. Ghani, 2019).

SI is the degree to which customers perceive that others (e.g., family and friends) believe they should use a specific technology (Venkatesh et al., 2012). Indeed, SI and intention to use m-banking have a significant connection (Kumar, Lall, \& Mane, 2017). FC is explained as the extent to which a person is certain that an organizational and technical infrastructure is available to support the use of the system (Venkatesh et al., 2003). On the other hand, m-banking usage requires a specific kind of skill and resources support (Alalwan et al., 2015). FC has a significant effect on user adoption (Zhou et al., 2010). Habit is defined as the degree to which people incline to perform behaviours repeatedly because of learning, it reflects that it is about regular, and automaticity and it is essential to understand the habit to improve the use of technology (Limayem et al., 2007). Because of its convenience and easy adaptability and its repeated use makes consumers addictive and gradually m-banking can become people's habit (Huili \& Chunfang, 2011). HM is the amusing or pleasure resultant from using technology, and it has been displayed to play a significant role in shaping technology acceptance and usage (Brown \& Venkatesh, 2005; Venkatesh et al., 2012). 
According to Alalwan et al. (2015), Internet banking adoption among consumers may increase if they perceive Internet banking as entertaining, pleasurable and enjoyable and the results of the study indicated that HM has a significant influence on BI. HM and HB have a positive effect on BI (Alalwan et al., 2015).

The term gamification (GM) was originated in the digital media industry. Its application is widespread and is used by various service providers to engage users and enhance participation (Deterding, Dixon, Khaled, \& Nacke, 2011). GM is the process of game-thinking and game mechanics to engage users and solve problems. It is about consumers' engagement, attracting through fun filed activities and motivate towards a specific behaviour change. GM is acknowledged as a vital set of activities concerning engagement and motivation. A study found that GM has a positive impact on BI. This reveals the importance that the usage of game mechanics and game design techniques can influence the m-banking usage intention, direct and strong association between gamification and intention towards usage of $\mathrm{m}$-banking services were traced from the evidences (Baptista \& Oliveira, 2017).

H2: BI is positively influenced by PE (H2a), EE (H2b), SI (H2c), FC (H2d), HB (H2e), HM (H2f), and $\mathrm{GM}(\mathrm{H} 2 \mathrm{~g})$.

The third block of hypothesis consists of factors affecting gamification. Scholars have revealed that social factors are a strong determinant of user intentions towards gamified services (C. H. Chung, Shen, \& Qiu, 2019; Hamari \& Koivisto, 2015). Moreover, FC is a significant factor influencing students to accept gamification (C. H. Chung et al., 2019). Game dynamics and mechanics affect the development of a habit through the mobile application. As no prior study has examined how habit influence gamification, the present study aims to contribute to this novelty. Habit is about repetitiveness, therefore, the present study aims to examine how a habit effects gamification. GM influences intention to use m-banking services targeting to augment the banking services by making an enjoyable and attractive experience. Therefore, $\mathrm{m}-$ banking attractiveness makes consumers habitual towards gamification. A study addressed the perception and usage of the gamified learning environment from a hedonic motivation perspective and found enjoyment is significant with BI (Oluwajana, Idowu, Nat, Vanduhe, \& Fadiya, 2019). On the other hand, gamification provides fun and pleasure to use technology, hence the study tried to investigate how HM affects gamification. Taking all together,

H3: Gamification is positively impacted by SI (H3a), FC (H3b), HB (H3c), and HM (H3d).

The fourth block of hypotheses is about the generational cohort and how it affects the relationship between gamification and BI. No prior study has covered it so far. To understand the influence of generation, what is expected to influence this relationship is the difference in characteristics of Gen Y and Z. Different generations reflect different characteristics based on the changes happening around the world. Generation cohorts classify generations in homogenous groups which reflect a similar attitude towards social and professional life. People born between 1979-1995 were named as Gen Y and they have witnessed the era of globalization. They have witnessed technology development and its application for easiness. On the other hand, Gen Z inclusive of people born after 1996, are born in the technological environment. They are brought up in mobile technology and technology is part of their daily life (Fromm \& Read, 2018). Considering this difference, it would be interesting to identify the generational differences impact on the relationship between gamification and behavioural intention to use mobile banking. According to Harris, Cox, Musgrove, \& Ernstberger (2016), though people of all ages now reflect an equal interest in emerging online technologies, comparatively, older customers perceive high value in conventional banking, and younger users are more attracted towards newest technologies. Another study stated that age reflects differences in information processing (Venkatesh et al., 2012). As gamification came into existence, gradually it gains acceptance among both the generations. Baptista \& Oliveira (Baptista \& Oliveira, 2017) claim that gamification can make banking services more enjoyable, fun-filed, and exciting, which can improve consumers' mobile banking services acceptance, involvement, and satisfaction. Gamification is expected to have more engagement among Gen $\mathrm{Z}$ as they are brought up in a similar digital environment (Zichermann \& Cunningham, 2011). Therefore, the current study extends the mentioned research by 
examining specifically generational perception and differences in the relationship between gamification and BI. Thus,

H4: Generational cohort moderates the relationship between GM and BI.

Regarding the fifth hypothesis, very limited research about the IR and actual recommendations are available, regardless of word-of-mouth IR popularity and importance among researchers (Keiningham, Cooil, Aksoy, Andreassen, \& Weiner, 2007). Recently, Mehrad \& Mohammadi (2017) found that word-ofmouth is the main variable influences users' attitudes toward the use of m-banking. From the user's behaviour perspective, satisfaction is a key factor of behavioural intentions, including IR (Finn, Wang, \& Frank, 2009). In simple words, intention to recommend may depend on the usage behaviour of consumers, either they have positive or negative. IR through social media and communication devices is influenced by the benefits gained through mobile payment technology. Therefore, the intention to recommend technology is a post-adoption behaviour (K. H. Chung \& Shin, 2010; Lancelot Miltgen, Popovič, \& Oliveira, 2013; Oliveira, Thomas, Baptista, \& Campos, 2016). Therefore,

H5: IR is positively affected by UB.

Figure 1 presents the conceptual framework of this study which has been designed to investigate the behaviour of m-banking users. The conceptual framework maps the hypotheses.

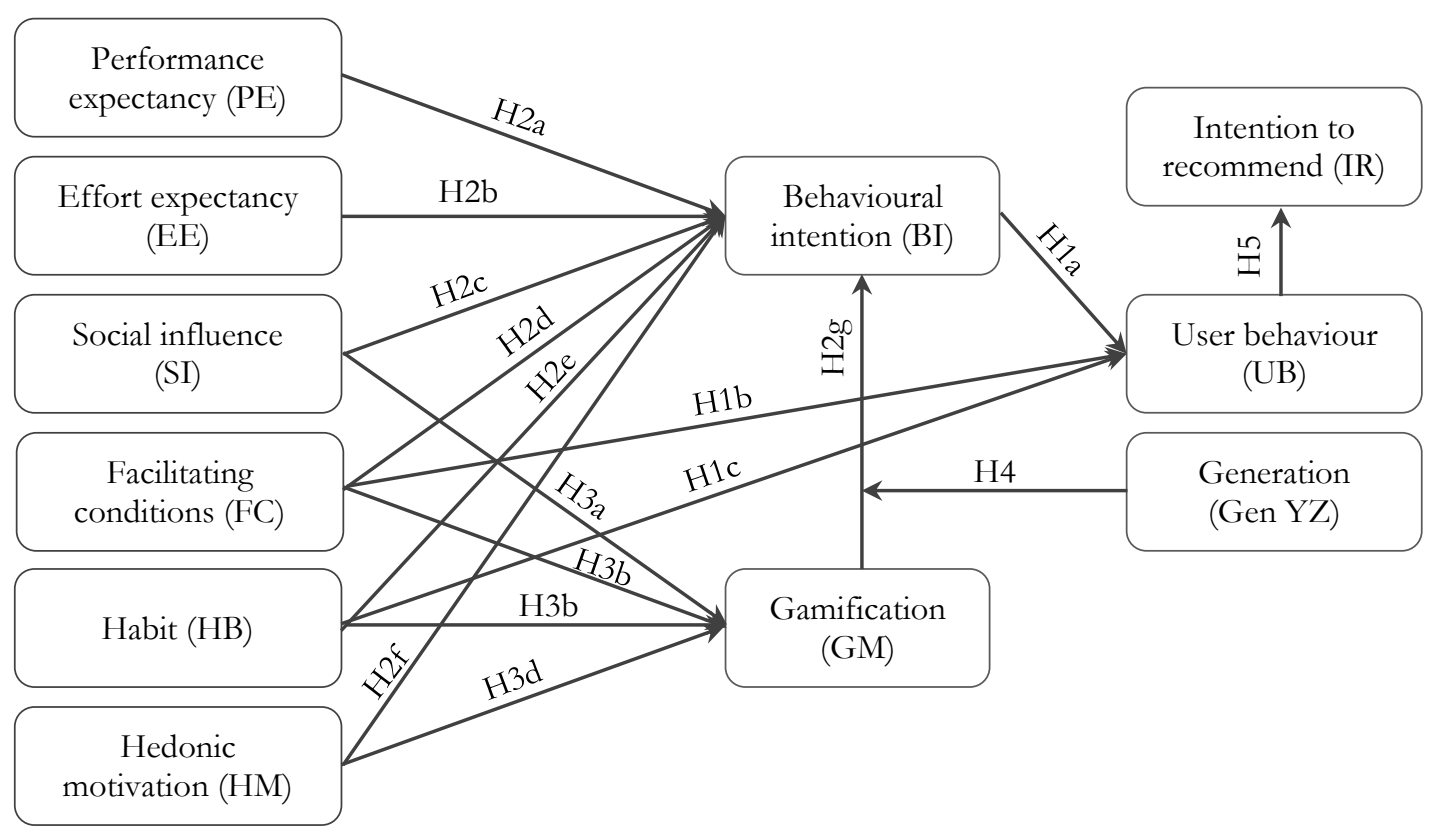

Figure 1. Theoretical model

\section{Data collection and research methodology}

To examine the proposed theoretical model, a questionnaire in English language was designed and reviewed for content validity by academics of the field. Afterwards, it was translated into the local language of Albania. The data collection tool has been chosen questionnaire due to the fact that previous research which investigate m-banking and UTAUT2 model followed identical data collection technique (Baptista \& Oliveira, 2017). The questionnaire contains three main sections: indicators of UTAUT2 constructs, gamification indicators, and demographic profile of the respondents. The items for the UTAUT2 constructs were adapted mainly from Venkatesh et al. (2003, 2012); the UB, IR and GM from Martins, Oliveira and Popovič (Martins, Oliveira, \& Popovič, 2014), Baptista and Oliveira (2017) and Sigala (2015). The original 
UTAUT2 (Venkatesh et al., 2012) includes even price value construct, however, it was not relevant for this research, since the mobile service in Albania is provided free of charge. The level of agreement for indicator have been measured with a five-point Likert scale ( $1=$ 'strongly disagree' to $5=$ 'strongly agree'). Within the questionnaire, UB scale was reworded from Martins et al. (Martins et al., 2014) aiming to measure the m-banking usage frequency. Since the respondents had used m-banking at least once in a year, the UB scale was modified from 11 into 10 answers by removing the 'never' answer: 1 = 'once a year', 2 = 'once in six months', $3=$ 'once in three months', $4=$ 'once a month', $5=$ 'once a week', $6=$ 'once in 4-5 days', $7=$ 'once in 2-3 days', 8 = 'almost every day', $9=$ 'every day', $10=$ 'several times a day'. Furthermore, the respondents were request to write the year they were born, however, for analysis purposes, codes used were 0 for Generation Z (covering respondents born after 1996) and 1 for Generation Y (respondents inborn between 1985 and 1996).

The convenience sampling technique has been followed due to the fact that the study focuses on the behaviour of m-banking users only. Thus, the target population consist of individuals (above 18 years old) who poses a mobile phone or tablet with internet access, have at least one bank accounts and have used mbanking at least once a year. Before distribution, a pilot test with 100 respondents randomly chosen was conducted, to be able to revise the accuracy of the translation and to ensure consistency. The gathered data from pilot test were not included in the final sample. The collection of the data took place during Spring 2019 in Albania. After filtering the final sample, 380 valid records were used for further analyses, above the suggested level of 200 (Bagozzi \& Yi, 2012).

Table 1 demonstrates the sample profile. Half of the sample consists of Generation $\mathrm{Z}$ individuals (49\%). The majority of the respondents were female (68.7\%). 15 in 100 respondents had high school as the highest level of education and the rest had at least university degree $(84 \%=52.4 \%$ university $+31.6 \%$ postuniversity and more). Concerning the employment status, approximately two in five respondents were unemployed. Regarding the occupation profile, the majority of those who were employed worked in the private sector $(78.6 \%), 16.3 \%$ in the public sector and $5.1 \%$ in both sectors. Further information regarding sample characteristics within generational cohorts are presented in Table 1. The sample profile correspond with the study conducted by Chaouali, Souiden and Ladhari (Chaouali, Souiden, \& Ladhari, 2017).

Table 1. Sample profile

\begin{tabular}{|llrr|rr|rr|}
\hline \multirow{2}{*}{ Category } & \multirow{2}{*}{ Sub-category } & \multicolumn{3}{c}{ Generational cohort } & \multicolumn{2}{c|}{ Total } \\
& & $\mathrm{Z}(n=188,49 \%)$ & $\mathrm{Y}(n=192,51 \%)$ & \multicolumn{1}{c|}{ Share } \\
\hline \multirow{3}{*}{ Gender } & Female & 134 & $71.3 \%$ & 127 & $66.1 \%$ & 261 & $68.7 \%$ \\
& Male & 54 & $28.7 \%$ & 65 & $33.9 \%$ & 119 & $31.3 \%$ \\
\cline { 2 - 8 } Employed & No & 121 & $64.4 \%$ & 44 & $22.9 \%$ & 165 & $43.4 \%$ \\
& Yes & 67 & $35.6 \%$ & 148 & $77.1 \%$ & 215 & $56.6 \%$ \\
\cline { 2 - 8 } Work & Public sector & 7 & $10.4 \%$ & 28 & $18.9 \%$ & 35 & $16.3 \%$ \\
& Private sector & 56 & $83.6 \%$ & 113 & $76.4 \%$ & 169 & $78.6 \%$ \\
& Both sectors & 4 & $6 \%$ & 7 & $4.7 \%$ & 11 & $5.1 \%$ \\
\hline
\end{tabular}

PLS-SEM was used to evaluate the variance of the internal cause of the constructs based on the proposed theoretical model and their corresponding manifest variables in turn (Hair, Hult, Ringle, \& Sarstedt, 2017). PLS-SEM was employed because constructs are not normally distributed and the current research requires latent variable scores for follow-up analyses (Hair, Risher, Sarstedt, \& Ringle, 2019). In addition, PLS performs convenient method in testing mediation effects because it provides an indication of relationship that is similar to the traditional regression coefficients. All constructs in the current study were modelled as reflective indicators. PLS-SEM was run through SmartPLS 3.0 computer software (Ringle, Wende, \& Becker, 2015). Firstly, the structural model was designed to assist in order to define the variables and their relationship. Secondly, the measurement model of the constructs were calculated initially to define the reliability, validity and discriminant validity to follow up with the demonstration of the relationships 
between the constructs (Hair et al., 2017). To identify the significance of these relationships the standardized paths were examined. These paths were calculated using the bootstrap procedure, with 1000 iterations of resampling.

\section{Findings}

\section{Measurement model}

Before testing the proposed theoretical model, the preliminary analyses has been followed. In this section are presented the core PLS-SEM assumptions dealing with collinearity, item loading, reliability and discriminant validity among constructs.

Initially all items per each construct in Table 2 were included in the analysis. Based on variance inflation factor (VIF) the first item of IR construct was removed, because it exceeded the threshold of 5 (Hair et al., 2019). Besides HB1, HB2, HB4, IR2, IR4 which had a slightly higher VIF value than 3, the ensuing indicators fulfilled the conservative threshold. The indicators were not removed due to the essential role within the construct (Hair et al., 2019).

In Table 2 are presented the item loadings, the Cronbach's alpha (CA), composite reliability (CR) and the average variance extracted (AVE) values. The lowest item loading (SI2 $=0.715)$ is slightly higher than the minimum required value of 0.708 (Hair et al., 2019). The CA coefficients are in the range of 0.75 to 0.92 , whereas CR value ranges from 0.84 to 0.95 , which meets the Hair et al.'s (Hair et al., 2019) suggested bounds $(0.70-0.95)$ by representing a good construct's internal consistency reliability, thus, the factor model is correct. Furthermore, AVE exceed the minimum criteria of 0.50 (Barclay, Higgins, \& Thompson, 1995; Hair, Black, Babin, \& Anderson, 2010; Hair et al., 2019; Urbach \& Ahlemann, 2010) and it varies from 0.56 to 0.89 which indicates that the constructs value explains at least half of the variance of its indicators demonstrating sufficient convergent validity. According to the complete bootstrapping output, all item loadings, CA, CR and AVE values were statistically significant $(p<0.001)$.

Table 2. Item loadings, Cronbach's alpha, composite reliability and average variance extracted

\begin{tabular}{|c|c|c|}
\hline & Construct and Items & Loading \\
\hline \multicolumn{3}{|c|}{$\mathrm{FC}(\mathrm{CA}=.92, \mathrm{CR}=.94, \mathrm{AVE}=.80)$ Source $:$ Venkatesh et al. $($ Venkatesh et al., 2003, 2012) } \\
\hline $\mathrm{FC} 1$ & $\begin{array}{l}\text { Mobile banking saves me time by avoiding going to the bank branches, waiting in the } \\
\text { queue }\end{array}$ & 0.890 \\
\hline FC2 & I have the necessary resources to use mobile banking services & 0.896 \\
\hline FC3 & the necessary knowledge to use mc & 0.889 \\
\hline FC4 & Mobile banking is compatible with other technologies I use & 0.906 \\
\hline \multicolumn{3}{|c|}{$\mathrm{PE}(\mathrm{CA}=.86, \mathrm{CR}=.91, \mathrm{AVE}=.78)$ Source: Venkatesh et al. $($ Venkatesh et al., 2003, 2012) } \\
\hline PE1 & Mobile banking services are very useful in my daily life & 0.910 \\
\hline PE2 & vices increases my productivity & 0.849 \\
\hline PE2 & Using mobile banking services helps me accomplish things more quickly & 0.887 \\
\hline \multicolumn{3}{|c|}{$\mathrm{EE}(\mathrm{CA}=.88, \mathrm{CR}=.94, \mathrm{AVE}=.89)$ Source $:$ Venkatesh et al. $($ Venkatesh et al., 2003, 2012) } \\
\hline EE1 & Learning how to use mobile banking services was easy for me & 0.944 \\
\hline EE2 & My interaction with mobile banking services is clear and understandable & 0.944 \\
\hline \multicolumn{3}{|c|}{ SI $(\mathrm{CA}=.75, \mathrm{CR}=.84, \mathrm{AVE}=.56)$ Source $:$ Venkatesh et al. $($ Venkatesh et al., 2003, 2012) } \\
\hline SI1 & People who are important to me suggested to use mobile banking services & 0.732 \\
\hline SI2 & rker suggested to use mobile banking services & 0.715 \\
\hline SI3 & Mobi & 0.761 \\
\hline SI4 & I believe that companies should support the use of mobile banking & 0.787 \\
\hline \multicolumn{3}{|c|}{$\mathrm{HB}(\mathrm{CA}=.90, \mathrm{CR}=.93, \mathrm{AVE}=.77)$ Source: Venkatesh et al. $($ Venkatesh et al., 2012) } \\
\hline HB1 & The use of mobile banking services has become a habit for me & 0.896 \\
\hline HB2 & I am addicted to using mobile banking services & 0.900 \\
\hline
\end{tabular}


HB3 I feel like I must use mobile banking services

HB4 Using mobile banking has become natural to me 0.905

$\mathrm{HM}(\mathrm{CA}=.82, \mathrm{CR}=.88, \mathrm{AVE}=.66)$ Source: Venkatesh et al. (Venkatesh et al., 2012) and Lin (Lin, 2011)

HM1 My curiosity is often stimulated by mobile banking app $\quad 0.757$

$\begin{array}{ll}\text { HM2 I enjoy using mobile banking } & 0.879\end{array}$

HM3 While using mobile banking, I felt a sense of adventure $\quad 0.809$

HM4 I use mobile banking to keep up with the trends 0.791

$\mathrm{GM}(\mathrm{CA}=.79, \mathrm{CR}=.86, \mathrm{AVE}=.61)$ Source: Baptista and Oliveira (Baptista \& Oliveira, 2017) and Sigala (Sigala, 2015)

GM1 If using mobile banking would give me points, rewards and prizes I would use more often 0.767

GM2 If mobile banking was more fun/enjoyable I probably would use it more often 0.811

GM3 Mobile banking helps me reach my financial achievements and deplete my creativity $\quad 0.810$

GM4 Mobile banking with animated and gamified elements facilitates the money management 0.726

$\mathrm{BI}(\mathrm{CA}=.88, \mathrm{CR}=.92, \mathrm{AVE}=.74)$ Source: Venkatesh et al. (Venkatesh et al., 2012) and Martins et al. (Martins et al., 2014)

BI1 I intend to continue using mobile banking in the future 0.866

BI2 I always try to use mobile banking in my daily life $\quad 0.874$

BI3 I intend to consult the balance of my account on the app of mobile banking 0.887

$\begin{array}{ll}\text { BI4 I intend to perform a transfer on the app of mobile banking } & 0.817\end{array}$

$\mathrm{IR}(\mathrm{CA}=.92, \mathrm{CR}=.95, \mathrm{AVE}=.86)$ Source: Oliveira et al. (Oliveira et al., 2016)

IR1 I will recommend to my friends to use the mobile banking service removed

IR2 I will recommend to my relatives to use the mobile banking service 0.936

IR3 I intend to recommend to my co-workers to use the mobile banking services 0.945

IR4 I intend to offer help to those I have recommended to use mobile banking 0.901

Note: CA, Cronbach's alpha; CR, composite reliability; AVE, average variance extracted; PE, performance expectancy; EE, effort expectancy; SI, social influence; FC, facilitating conditions; HM, hedonic motivation; HB: habit; GM, gamification; BI,

behavioural intention; IR, intention to recommend.

The analyse continues with the investigation of discriminant validity. Since PLS is a variance-based SEM, for discriminant validity assessment it was applied the Heterotrait-Monotrait (HTMT) criteria (Henseler, Ringle, \& Sarstedt, 2015). The HTMT coefficients (see Table 3, above the diagonal) were below the conservative threshold of 0.85 (Henseler et al., 2015). Consequently, the measured constructs satisfy the assumption of discriminant validity.

Table 3. Discriminant analysis with Heterotrait-Monotrait (HTMT) ratio and correlation matrixes

\begin{tabular}{|c|cccccccccc|}
\hline & FC & PE & EE & SI & HB & HM & GM & BI & IR & UB \\
\hline FC & & 0.716 & 0.776 & 0.678 & 0.455 & 0.514 & 0.527 & 0.623 & 0.671 & 0.240 \\
PE & 0.802 & & 0.735 & 0.699 & 0.480 & 0.475 & 0.475 & 0.624 & 0.609 & 0.289 \\
EE & 0.697 & 0.844 & & 0.562 & 0.380 & 0.422 & 0.415 & 0.497 & 0.587 & 0.218 \\
SI & 0.606 & 0.595 & 0.493 & & 0.492 & 0.543 & 0.447 & 0.547 & 0.563 & 0.217 \\
HB & 0.421 & 0.543 & 0.344 & 0.585 & & 0.596 & 0.461 & 0.681 & 0.609 & 0.389 \\
HM & 0.461 & 0.549 & 0.369 & 0.667 & 0.523 & & 0.582 & 0.548 & 0.543 & 0.102 \\
GM & 0.467 & 0.560 & 0.360 & 0.558 & 0.536 & 0.709 & & 0.501 & 0.560 & 0.097 \\
BI & 0.690 & 0.714 & 0.564 & 0.639 & 0.756 & 0.625 & 0.583 & & 0.808 & 0.365 \\
IR & 0.616 & 0.684 & 0.528 & 0.651 & 0.555 & 0.489 & 0.488 & 0.728 & & 0.283 \\
UB & 0.229 & 0.266 & 0.204 & 0.187 & 0.377 & 0.106 & 0.082 & 0.343 & 0.272 & \\
\hline
\end{tabular}

Note: $\mathrm{N}=380$. The HTMT coefficients are above the diagonal, whereas correlation coefficients are below it. 


\section{Structural model}

Following the fulfilment of PLS-SEM assumption, the examination of structural model has been completed (see Table 4). The model explains $15.7 \%$ of the variation in UB, $63.5 \%$ in BI, $40.7 \%$ in GM, and $7.4 \%$ in IR. Based on our conceptual framework, UB is determined by FC, HB and BI. Hence, UB is positively affected by BI $(\beta=0.145, p<0.1)$ and $\mathrm{HB}(\beta=0.268, p<0.001)$. Therefore, sufficient evidence have been identified to support H1a and H1c. The relationship between FC and UB resulted insignificant $(\beta=0.026$, $p>0.10)$. Regarding BI, constructs which statistically impact were $\mathrm{PE}(\beta=0.175, p<0.01), \mathrm{FC}(\beta=0.257$, $p<0.001)$, HB $(\beta=0.405, p<0.001)$, and HM $(\beta=0.096, p<0.1)$. The influence of EE and SI along with the main effect of GM over BI resulted insignificant. However, the moderation effect of GM through Gen YZ on BI was significant $(\beta=0.069, p<0.05)$. Following the Kenny's (2018) benchmarks, the moderation effect size was medium $\left(f^{2}=0.013\right)$. Thus, H2a, H2d, H2e, H2f and H4 were supported.

Table 4. Structural model evaluation

\begin{tabular}{|c|c|c|c|c|c|c|}
\hline Path & Standardized estimate $(\beta)$ & $t$ & $p$ & $\mathrm{R}^{2}$ & Hypothesis & Supported \\
\hline $\mathrm{BI} \rightarrow \mathrm{UB}$ & 0.145 & 1.887 & 0.059 & & H1a & Yes \\
\hline $\mathrm{FC} \rightarrow \mathrm{UB}$ & 0.026 & 0.376 & 0.707 & & $\mathrm{H} 1 \mathrm{~b}$ & No \\
\hline \multirow[t]{2}{*}{$\mathrm{HB} \rightarrow \mathrm{UB}$} & 0.268 & 4.144 & 0.000 & & $\mathrm{H} 1 \mathrm{c}$ & Yes \\
\hline & & & & 0.157 & & \\
\hline $\mathrm{PE} \rightarrow \mathrm{BI}$ & 0.175 & 2.906 & 0.004 & & $\mathrm{H} 2 \mathrm{a}$ & Yes \\
\hline $\mathrm{EE} \rightarrow \mathrm{BI}$ & -0.014 & 0.274 & 0.784 & & $\mathrm{H} 2 \mathrm{~b}$ & No \\
\hline $\mathrm{SI} \rightarrow \mathrm{BI}$ & 0.018 & 0.427 & 0.669 & & $\mathrm{H} 2 \mathrm{c}$ & No \\
\hline $\mathrm{FC} \rightarrow \mathrm{BI}$ & 0.257 & 4.794 & 0.000 & & $\mathrm{H} 2 \mathrm{~d}$ & Yes \\
\hline $\mathrm{HB} \rightarrow \mathrm{BI}$ & 0.405 & 7.876 & 0.000 & & $\mathrm{H} 2 \mathrm{e}$ & Yes \\
\hline $\mathrm{HM} \rightarrow \mathrm{BI}$ & 0.096 & 1.878 & 0.061 & & $\mathrm{H} 2 \mathrm{f}$ & Yes \\
\hline $\mathrm{GM} \rightarrow \mathrm{BI}$ & 0.046 & 0.855 & 0.393 & & $\mathrm{H} 2 \mathrm{~g}$ & No \\
\hline Gen $\mathrm{YZ} \rightarrow \mathrm{BI}$ & 0.014 & 0.438 & 0.661 & & & \\
\hline \multirow[t]{2}{*}{$\mathrm{GM}^{*} \mathrm{Gen} \mathrm{YZ} \rightarrow \mathrm{BI}$} & $0.069^{\mathrm{a}}$ & 1.973 & 0.049 & & H4 & Yes \\
\hline & & & & 0.635 & & \\
\hline $\mathrm{SI} \rightarrow \mathrm{GM}$ & 0.039 & 0.652 & 0.514 & & $\mathrm{H} 3 \mathrm{a}$ & No \\
\hline $\mathrm{FC} \rightarrow \mathrm{GM}$ & 0.200 & 3.376 & 0.001 & & $\mathrm{H} 3 \mathrm{~b}$ & Yes \\
\hline $\mathrm{HB} \rightarrow \mathrm{GM}$ & 0.155 & 2.575 & 0.010 & & $\mathrm{H} 3 \mathrm{c}$ & Yes \\
\hline \multirow[t]{2}{*}{$\mathrm{HM} \rightarrow \mathrm{GM}$} & 0.387 & 7.119 & 0.000 & & $\mathrm{H} 3 \mathrm{~d}$ & Yes \\
\hline & & & & 0.407 & & \\
\hline $\mathrm{UB} \rightarrow \mathrm{IR}$ & 0.272 & 5.237 & 0.000 & 0.074 & H5 & Yes \\
\hline
\end{tabular}

Regarding GM, which resulted to be positively influenced by FC $(\beta=0.2, p<0.01), \mathrm{HB}(\beta=0.155, p<$ $0.05)$, and $\mathrm{HM}(\beta=0.387, p<0.001)$. SI effect on GM was insignificant, $\beta=0.039, p>0.10$. The effect of UB over IR was positively significant, $\beta=0.272, p<0.001$. Therefore, H3b, H3c, H3d and H5 were supported.

\section{Discussions}

Integrating the extended UTAUT2 model (Venkatesh et al., 2012), gamification (Deterding, Sicart, Nacke, O'Hara, \& Dixon, 2011) and generational cohort theory (Inglehart, 2015), the current study investigate the factors which impact on m-banking usage and its focus consists on Albanians intention to use m-banking. Moreover, the determinants of UB and its effect on IR were examined. Additionally, the novelty of this study consists on the moderating effect of generational cohorts into the relationship between BI and GM. 
The results of this study reveal that BI determinants are PE, FC, HB and HM. The results are in the same line with previous research conducted (Gharaibeh \& Mohd Arshad, 2018; E. Tan \& Leby Lau, 2016; Venkatesh et al., 2012). Indicating that creating an efficient, simply, enjoyable mobile app impact on the intention to use the mobile app to perform financial transactions. Regarding the influence FC on BI, the results dissimilarities' with the previous research has been identified (Baptista \& Oliveira, 2017; Goularte \& Zilber, 2018; Oliveira et al., 2016) whereas a positive and significant relationship has been noted. Contradicting the prior studies (Goularte \& Zilber, 2018; Jamshidi, Keshavarz, Kazemi, \& Mohammadian, 2018; Martins et al., 2014; Oliveira et al., 2016), EE and SI were reported as insignificant determinants of BI. Indicating that when is a matter of financial capital m-banking users are unconcerned and indifferent regarding the opinion, thoughts and emotions of relatives and siblings.

The main effect of GM on BI was insignificant contradicting previous studies (Baptista \& Oliveira, 2017; Rodrigues, Costa, \& Oliveira, 2017). According to Thiebes, Lins and Basten (2014) 80\% of cases where game elements were employed failed due to poor design and inappropriate appliance. The results of this study confirm the lack of game elements design and appliance impact. However, the current research discovered the relationship as statistically moderated by generational cohorts. As indicated by the PLSSEM analysis, when compared to Gen Z, individuals who score high on GM and have born before 1996 (Gen Y) reflect higher intention to use m-banking, whereas those with low GM score have lower such intentions (see Figure 2). Consequently, different BI levels may be achieved through the application of game elements within generational cohorts.

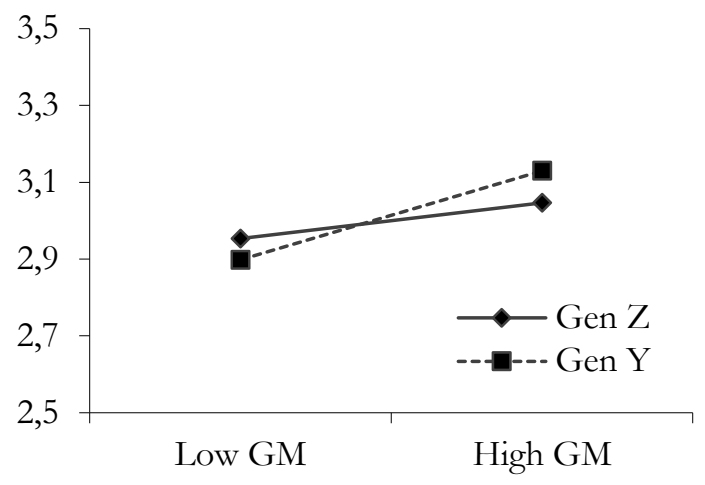

Figure 2. The moderating effect on BI

The finding comprehensible shed light on the Gen Z individuals' easiness adoption of game elements within app usage, compared with the individuals of Gen Y. Nine out of ten Gen Z individuals own a smartphone and have a digital footprint which qualifies as frequent smartphone user. In addition, reports (Desjardins, 2019) presents that $40 \%$ of Gen $Y$ admit the smartphone addiction and eight in ten Gens $Z$ tend to distressed when kept away from personal electronic devices. Consequently, young generation consider as adjustable the technological changes. Similar trend has been confirmed within the study.

Concerning the determinants of GM, the PLS-SEM analysis reported that FC, HB and HM are significant. According to Hanus and Fox (2015), between HM and GM is a positive association. Nevertheless, the effect of SI on GM resulted insignificant, which contradicts the Hamari and Koivisto's (Hamari \& Koivisto, 2015) findings. Indicating that game elements should be employed to induce the usage experience with fun and joy followed with simply feature incorporated within the mobile app.

$\mathrm{BI}$ and $\mathrm{HB}$ positively and statistically influence the use of m-banking, which is consistent with the prior study conducted in this field (Baptista \& Oliveira, 2017; Martins et al., 2014). Signifying that users have grater opportunities to use m-banking if the intention to use is embody and the m-banking is used regullary to perform financial transactions. Contradicting the initial expectation of this study and the factors which impact BI, the impact of FC on UB was insignificant, which converges the prior findings (Goularte \& 
Zilber, 2018; Martins et al., 2014). The contradicting results may be as a results of app characteristics, simplicity and design.

As it was foreseen, IR is positively predicted by UB. Indicating that the positive or negative experience is expected to be shared. The recommandations provided by m-banking users impact on potential users due to the fact that word-of-mouth is consider as a powerful mean of marketing communication (King, Racherla, $\&$ Bush, 2014). However, the effect size was reported as weak $\left(\mathrm{R}^{2}=7.4 \%\right)$. On the other side, Oliveira et al. (2016) found a higher effect size of the relationship between BI and IR $\left(R^{2}=61.3 \%\right)$. An attentively observation on the correlation coefficients (see Table 3 ) may clarify the great imbalance of effect sizes. The correlation between IB and IR is 2.7 times higher compare with the correlation between UB and IR $(r=$ 0.272). Presuming that IR determinant had been BI instead of UB, a stronger effect size would be achieved. Thusly, the results converges prior studies (Oliveira et al., 2016; Rahi \& Abd. Ghani, 2019).

\section{Conclusions, limitations and recommendations}

The research provides insights regarding influential factors on behaviour intention, user behaviour, gamification and intention to recommend m-banking. Thus, the current research makes an important contribution concerning customer behaviour in m-banking and its determinants. The theoretical background of the study leans on modified UTAUT2 model (Venkatesh et al., 2012), gamification (Deterding, Sicart, et al., 2011) and generational cohorts theory (Inglehart, 2015) establishing an attractive combination of constructs and its impact on m-banking users in the context of a transition country.

To authors' knowledge, the current study is among the first which theoretically explain and empirical examine the moderation effect of gamification on intention to use m-banking through generational cohorts. However, prior studies have demonstrated the importance of gamification (Hamari \& Koivisto, 2015) and its influence on individuals' intention to use m-banking (Baptista \& Oliveira, 2017; Rahi \& Abd. Ghani, 2019; Rodrigues et al., 2017), while the current research emphasises the role of generational cohorts which moderates the effect of gamification on intention to use m-banking.

From a managerial perspective, bank managers are in favour of offering services remotely, due to diminish operational costs. For banks, technological advancements create competitive advantages by allowing companies to invest on services improvement. Operating banks in transition countries are adviced to follow the similar trends accros the glob regarding m-banking services due to its beneficial obtainability for banks and clients. An enhanced bank strategy which would employ game elements is expected to encourage clients to use and recommend the $\mathrm{m}$-banking services. The similar evidence regarding motivation to use $\mathrm{m}$ banking have been identified previously, whereas points (game mechanics element) motivated app usage (Chaouali et al., 2017). Furthermore, the results of current study assist banks concerning additional effort required to encourage individuals belonging to Gen Y to use m-banking services, rather than Gen Z.

The current study has its limitations which may be consider as invitation for further research by academic and researchers. Beginning with the sample, the study is biased due to its lack of comparision with nonusers. Eventually, investigating the obstacles which prohibit nonusers to use m-banking may assist banks to increase the usage of m-banking. Although the majority constructs appeared to be significant, further research may employ trust, information asymmetry, perceived risk, personal innovativeness. Furthermore, modifying the model by adding different variables based on cultural and economic background might provide attractive results. Also, modifying the gamification construct by incorporating other game elements to obtain additional information regarding game elements impact on m-banking users could provide important insight. Nevertheless, Albania might share similarities with other countries in terms of economic progress and technology advancements in banking services sectors the results of this study are limited to one country. Limited research has been conducted in Albania regarding the reasons to continue using $\mathrm{m}-$ banking services as suggested by Shaikh et al. (2015b) which may be incorporated within the model. Lastly, additional demographic variables as moderators such as gender, region, education, occupation and income level could be included within the model to broaden the influenctial factors on usage of m-banking services. 


\section{References}

Ajzen, I. (1991). The theory of planned behavior. Organizational Behavior and Human Decision Processes, 50(2), 179-211. https://doi.org/10.1016/0749-5978(91)90020-T

Al-Jabri, B. M., \& Sohail, M. S. (2012). Mobile banking adoption: Application of diffusion of innovation theory. Journal of Electronic Commerce Research, 13(4), 379-391.

Alalwan, A. A., Dwivedi, Y. K., Rana, N. P., Lal, B., \& Williams, M. D. (2015). Consumer adoption of Internet banking in Jordan: Examining the role of hedonic motivation, habit, self-efficacy and trust. Journal of Financial Services Marketing, 20(2), 145-157. https://doi.org/10.1057/fsm.2015.5

Ameen, N., Willis, R., \& Hussain Shah, M. (2018). An examination of the gender gap in smartphone adoption and use in Arab countries: A cross-national study. Computers in Human Behavior, 89, 148162. https://doi.org/10.1016/j.chb.2018.07.045

Baabdullah, A. M., Alalwan, A. A., Rana, N. P., Kizgin, H., \& Patil, P. (2019). Consumer use of mobile banking (M-Banking) in Saudi Arabia: Towards an integrated model. International Journal of Information Management, 44, 38-52. https://doi.org/10.1016/j.ijinfomgt.2018.09.002

Bagozzi, R. P., \& Yi, Y. (2012). Specification, evaluation, and interpretation of structural equation models. Journal of the Academy of Marketing Science, 4O(1), 8-34. https://doi.org/10.1007/s11747-011-0278$\mathrm{x}$

Bank of Albania. (2018). The Retail Payment Costs and Savings in Albania. Tiranë.

Bank of Albania. (2019). Homebanking transactions 2005-2019. Tirana.

Baptista, G., \& Oliveira, T. (2017). Why so serious? Gamification impact in the acceptance of mobile banking services. Internet Research, 27(1), 118-139. https://doi.org/10.1108/IntR-10-2015-0295

Barclay, D. W., Higgins, C. A., \& Thompson, R. (1995). The partial least squares (PLS) approach to causal modeling: Personal computer adoption and use as an illustration. Technology Studies: Special Issue on Research Methodology, 2(2), 284-324.

Barnes, S. J., \& Corbitt, B. (2003). Mobile banking: concept and potential. International Journal of Mobile Communications, 1(3), 273-288. https://doi.org/10.1504/IJMC.2003.003494

Bhatiasevi, V. (2016). An extended UTAUT model to explain the adoption of mobile banking. Information Development, 32(4), 799-814. https://doi.org/10.1177/0266666915570764

Brown, S. A., \& Venkatesh, V. (2005). Model of adoption of technology in households: A baseline model test and extension incorporating household life cycle. MIS Quarterly: Management Information Systems, 29(3), 399-426. https://doi.org/10.2307/25148690

Carlsson, C., Carlsson, J., Hyvönen, K., Puhakainen, J., \& Walden, P. (2006). Adoption of mobile devices/services - Searching for answers with the UTAUT. In Proceedings of the Annual Hawaii International Conference on System Sciences (Vol. 6, pp. 01-10). https://doi.org/10.1109/HICSS.2006.38

Chaouali, W., Souiden, N., \& Ladhari, R. (2017). Explaining adoption of mobile banking with the theory of trying, general self-confidence, and cynicism. Journal of Retailing and Consumer Services, 35, 5767. https://doi.org/10.1016/J.JRETCONSER.2016.11.009

Chung, C. H., Shen, C., \& Qiu, Y. Z. (2019). Students' acceptance of gamification in higher education. International Journal of Game-Based Learning, 9(2), 1-19. https://doi.org/10.4018/IJGBL.2019040101 
Chung, K. H., \& Shin, J. I. (2010). The antecedents and consequents of relationship quality in internet shopping. Asia Pacific Journal of Marketing and Logistics, 22(4), 473-491. https://doi.org/10.1108/13555851011090510

Compeau, D. R., \& Higgins, C. A. (1995). Computer Self-Efficacy: Development of a Measure and Initial Test. MIS Quarterly, 19(2), 189. https://doi.org/10.2307/249688

Davis, F. D. (1989). Perceived Usefulness, Perceived Ease of Use, and User Acceptance of Information Technology. MIS Quarterly, 13(3), 319. https://doi.org/10.2307/249008

Davis, F. D., Bagozzi, R. P., \& Warshaw, P. R. (1992). Extrinsic and Intrinsic Motivation to Use Computers in the Workplace. Journal of Applied Social Psychology, 22(14), 1111-1132. https://doi.org/10.1111/j.1559-1816.1992.tb00945.x

Desjardins, J. (2019). Meet Generation Z: The Newest Member to the Workforce. Retrieved July 27, 2019, from https://www.visualcapitalist.com/meet-generation-z-the-newest-member-to-the-workforce/

Deterding, S., Dixon, D., Khaled, R., \& Nacke, L. (2011). From Game Design Elements to Gamefulness: Defining "Gamification." In MindTrek '11: Proceedings of the 15th International Academic MindTrek Conference: Envisioning Future Media Environments (Vol. 185, pp. 09-15).

Deterding, S., Sicart, M., Nacke, L., O’Hara, K., \& Dixon, D. (2011). Gamification. using game-design elements in non-gaming contexts. In Proceedings of the 2011 annual conference extended abstracts on Human factors in computing systems - CHI EA '11. https://doi.org/10.1145/1979742.1979575

Engotoit, B., Kituyi, G. M., \& Moya, M. B. (2016). Influence of performance expectancy on commercial farmers' intention to use mobile-based communication technologies for agricultural market information dissemination in Uganda. Journal of Systems and Information Technology, 18(4), 346363. https://doi.org/10.1108/JSIT-06-2016-0037

Finn, A., Wang, L., \& Frank, T. (2009). Attribute Perceptions, Customer Satisfaction and Intention to Recommend E-Services. Journal of Interactive Marketing, 23(3), 209-220. https://doi.org/10.1016/j.intmar.2009.04.006

Fishbein, M., \& Ajzen, I. (1975). Belief, attitude, intention, and behavior: An introduction to theory and research. Addison-Wesley.

Fromm, J., \& Read, A. (2018). Marketing to Gen Z. New York: AMACOM.

Galetta, G. (2013). The Gamification: Applications and Developments for Creativity and Education. In Creativity and Innovation in Education (Vol. 2, pp. 1-10). https://doi.org/10.13140/RG

Gharaibeh, M. K., \& Mohd Arshad, M. R. (2018). Determinants of intention to use mobile banking in the North of Jordan: Extending UTAUT2 with mass media and trust. Journal of Engineering and Applied Sciences, 13(8), 2023-2033. https://doi.org/10.3923/jeasci.2018.2023.2033

Goularte, A. da C., \& Zilber, S. N. (2018). The moderating role of cultural factors in the adoption of mobile banking in Brazil. International Journal of Innovation Science, 11(1), 63-81. https://doi.org/10.1108/IJIS-11-2017-0119

Hair, J. F., Black, W. C., Babin, B. J., \& Anderson, R. E. (2010). Multivariate Data Analysis (7th Editio). Harlow: Pearson Education Limited.

Hair, J. F., Hult, G. T. M., Ringle, C. M., \& Sarstedt, M. (2017). A Primer on Partial Least Squares Structural Equation Modeling (2nd ed.). Los Angelos: Sage.

Hair, J. F., Risher, J. J., Sarstedt, M., \& Ringle, C. M. (2019). When to use and how to report the results of PLS-SEM. European Business Review, 31(1), 2-24. https://doi.org/10.1108/EBR-11-2018-0203 
Hamari, J., \& Koivisto, J. (2015). "Working out for likes": An empirical study on social influence in exercise gamification. Computers in Human Behavior. https://doi.org/10.1016/j.chb.2015.04.018

Hanus, M. D., \& Fox, J. (2015). Assessing the effects of gamification in the classroom: A longitudinal study on intrinsic motivation, social comparison, satisfaction, effort, and academic performance. Computers and Education. https://doi.org/10.1016/j.compedu.2014.08.019

Harris, M., Cox, K. C., Musgrove, C. F., \& Ernstberger, K. W. (2016). Consumer preferences for banking technologies by age groups. International Journal of Bank Marketing, 34(4), 587-602. https://doi.org/10.1108/IJBM-04-2015-0056

Henseler, J., Ringle, C. M., \& Sarstedt, M. (2015). A new criterion for assessing discriminant validity in variance-based structural equation modeling. Journal of the Academy of Marketing Science, 43(1), 115-135. https://doi.org/10.1007/s11747-014-0403-8

Huili, Y., \& Chunfang, Z. (2011). The analysis of influencing factors and promotion strategy for the use of mobile banking. Canadian Journal of Social Science, 7(2), 60-63.

Inglehart, R. (2015). The silent revolution: changing values and political styles among Western publics. Princeton: Princeton University Press.

Jamshidi, D., Keshavarz, Y., Kazemi, F., \& Mohammadian, M. (2018). Mobile banking behavior and flow experience An integration of utilitarian features, hedonic features and trust. International Journal of Social Economics, 45(1), 57-81. https://doi.org/10.1108/IJSE-10-2016-0283

Keiningham, T. L., Cooil, B., Aksoy, L., Andreassen, T. W., \& Weiner, J. (2007). The value of different customer satisfaction and loyalty metrics in predicting customer retention, recommendation, and share-of-wallet. Managing Service Quality: An International Journal, 17(4), 361-384. https://doi.org/10.1108/09604520710760526

Kenny, D. (2018). Moderation. Retrieved from http://davidakenny.net/cm/moderation.htm

Kim, J. T., \& Lee, W.-H. (2015). Dynamical model for gamification of learning (DMGL). Multimedia Tools and Applications, 74(19), 8483-8493. https://doi.org/10.1007/s11042-013-1612-8

King, R. A., Racherla, P., \& Bush, V. D. (2014). What we know and don't know about online word-ofmouth: A review and synthesis of the literature. Journal of Interactive Marketing, 28(3), 167-183. https://doi.org/10.1016/j.intmar.2014.02.001

Kumar, V. V. R., Lall, A., \& Mane, T. (2017). Extending the TAM Model: Intention of Management Students to Use Mobile Banking: Evidence from India. Global Business Review, 18(1), 238-249. https://doi.org/10.1177/0972150916666991

Kwateng, K. O., Atiemo, K. A. O., \& Appiah, C. (2019). Acceptance and use of mobile banking: an application of UTAUT2. Journal of Enterprise Information Management, 32(1), 118-151. https://doi.org/10.1108/JEIM-03-2018-0055

Lancelot Miltgen, C., Popovič, A., \& Oliveira, T. (2013). Determinants of end-user acceptance of biometrics: Integrating the "Big 3" of technology acceptance with privacy context. Decision Support Systems, 56, 103-114. https://doi.org/10.1016/j.dss.2013.05.010

Langfield, S., \& Pagano, M. (2015). Bank bias in Europe: effects on systemic risk and growth (No. 1797). ECB Working Paper Series. Frankfurt.

Laukkanen, T., \& Pasanen, M. (2008). Mobile banking innovators and early adopters: How they differ from other online users? Journal of Financial Services Marketing, 13(2), 86-94. https://doi.org/10.1057/palgrave.fsm.4760077 
Limayem, M., Hirt, S. G., \& Cheung, C. M. K. (2007). How habit limits the predictive power of Intention. MIS Quarterly, 31(4), 705-737/. https://doi.org/10.1002/fut.10029

Lin, H.-H. (2011). Gender differences in the linkage of online patronage behavior with TV-and-online shopping values. Service Business, 5(4), 295-312. https://doi.org/10.1007/s11628-011-0115-9

Lissitsa, S., \& Kol, O. (2016). Generation X vs. Generation Y - A decade of online shopping. Journal of Retailing and Consumer Services, 31, 304-312. https://doi.org/10.1016/j.jretconser.2016.04.015

Martins, C., Oliveira, T., \& Popovič, A. (2014). Understanding the Internet banking adoption: A unified theory of acceptance and use of technology and perceived risk application. International Journal of Information Management, 34(1), 1-13. https://doi.org/10.1016/J.IJINFOMGT.2013.06.002

Mehrad, D., \& Mohammadi, S. (2017). Word of Mouth impact on the adoption of mobile banking in Iran. Telematics and Informatics, 34(7), 1351-1363. https://doi.org/10.1016/j.tele.2016.08.009

Meriac, J. P., Woehr, D. J., \& Banister, C. (2010). Generational differences in work ethic: An examination of measurement equivalence across three cohorts. Journal of Business and Psychology. https://doi.org/10.1007/s10869-010-9164-7

Moazenzadeh, D., \& Hamidi, H. (2018). Analysis and Development of Technology Acceptance Model in Mobile Bank Field. International Journal of Engineering, 31(9), 1521-1528. https://doi.org/10.5829/ije.2018.31.09c.07

Naicker, V., \& Van Der Merwe, D. B. (2018). Managers' perception of mobile technology adoption in the Life Insurance industry. Information Technology and People, 31(2), 507-526. https://doi.org/10.1108/ITP-09-2016-0212

Oliveira, T., Thomas, M., Baptista, G., \& Campos, F. (2016). Mobile payment: Understanding the determinants of customer adoption and intention to recommend the technology. Computers in Human Behavior, 61, 404-414. https://doi.org/10.1016/J.CHB.2016.03.030

Oluwajana, D., Idowu, A., Nat, M., Vanduhe, V., \& Fadiya, S. (2019). The adoption of students' hedonic motivation system model to gamified learning environment. Journal of Theoretical and Applied Electronic Commerce Research, 14(3), 156-167. https://doi.org/10.4067/S071818762019000300109

Park, J., Yang, S., \& Lehto, X. (2007). Adoption of Mobile Technologies for Chinese Consumers. Journal of Electronic Commerce Research, 8(3), 196-206. https://doi.org/10.1.1.92.2520

Parment, A. (2013). Generation Y vs. Baby Boomers: Shopping behavior, buyer involvement and implications for retailing. Journal of Retailing and Consumer Services. https://doi.org/10.1016/j.jretconser.2012.12.001

Rahi, S., \& Abd. Ghani, M. (2019). Does gamified elements influence on user's intention to adopt and intention to recommend internet banking? International Journal of Information and Learning Technology, 36(1), 2-20. https://doi.org/10.1108/IJILT-05-2018-0045

Ringle, C. M., Wende, S., \& Becker, J.-M. (2015). SmartPLS. Boenningstedt: SmartPLS GmbH. Retrieved from http://www.smartpls.com

Rodrigues, L. F., Costa, C. J., \& Oliveira, A. (2017). How does the web game design influence the behavior of e-banking users? Computers in Human Behavior, 74, 163-174. https://doi.org/10.1016/j.chb.2017.04.034

Rogers, E. M. (1995). Diffusion of innovations (3rd ed.). New York: The Free Press.

Shaikh, A. A., Karjaluoto, H., \& Chinje, N. B. (2015a). Consumers' perceptions of mobile banking 
continuous usage in Finland and South Africa. International Journal of Electronic Finance, 8(2-4), 149-168. https://doi.org/10.1504/IJEF.2015.070528

Shaikh, A. A., Karjaluoto, H., \& Chinje, N. B. (2015b). Continuous mobile banking usage and relationship commitment - A multi-country assessment. Journal of Financial Services Marketing, 20(3), 208-219. https://doi.org/10.1057/fsm.2015.14

Sigala, M. (2015). The application and impact of gamification funware on trip planning and experiences: the case of TripAdvisor's funware. Electronic Markets, 25(3), 189-209. https://doi.org/10.1007/s12525-014-0179-1

Tan, E., \& Leby Lau, J. (2016). Behavioural intention to adopt mobile banking among the millennial generation. Young Consumers, 17(1), 18-31. https://doi.org/10.1108/YC-07-2015-00537

Tan, W. K. (2018). Gamification in aquarium context: Intention to play game that imparts knowledge and promotes marine animal conservation. Information Technology and People, 31(6), 1070-1090. https://doi.org/10.1108/ITP-02-2017-0054

Taylor, S., \& Todd, P. A. (1995). Understanding information technology usage: A test of competing models. Information Systems Research, 6(2), 144-176. https://doi.org/10.1287/isre.6.2.144

Thiebes, S., Lins, S., \& Basten, D. (2014). Gamifying information systems-a synthesis of gamification mechanics and dynamics. In Twenty Second European Conference on Information Systems, Tel Aviv 2014 (pp. 1-17). Tel Aviv: The European Conferences of Information Systems.

Thompson, R. L., Higgins, C. A., \& Howell, J. M. (1991). Personal computing: toward a conceptual model of utilization. MIS Quarterly, 15(1), 125-143. https://doi.org/10.2307/249443

Thongsri, N., Shen, L., Bao, Y., \& Alharbi, I. M. (2018). Integrating UTAUT and UGT to explain behavioural intention to use M-learning: A developing country's perspective. Journal of Systems and Information Technology, 20(3), 278-297. https://doi.org/10.1108/JSIT-11-2017-0107

Urbach, N., \& Ahlemann, F. (2010). Structural Equation Modeling in Information Systems Research Using Partial Least Squares. Journal of Information Technology Theory and Application, 11(2), 5-40.

Vella, J., Wallström, Å., \& Farshid, M. (2017). Financial services Apps: What makes the difference between a great and a ghastly review? Journal of Financial Services Marketing, 22(3), 132-138. https://doi.org/10.1057/s41264-017-0031-8

Venkatesh, V., Morris, M. G., Davis, G. B., \& Davis, F. D. (2003). User Acceptance of Information Technology: Toward a Unified View. MIS Quarterly, 27(3), 425. https://doi.org/10.2307/30036540

Venkatesh, V., Thong, J. Y. L., \& Xu, X. (2012). Consumer acceptance and use of information technology: Extending the unified theory of acceptance and use of technology. MIS Quarterly, 36, 157-178.

Zhou, T., Lu, Y., \& Wang, B. (2010). Integrating TTF and UTAUT to explain mobile banking user $\begin{array}{lllll}\text { adoption. } \quad \text { Computers } & \text { 760-767. }\end{array}$ https://doi.org/10.1016/J.CHB.2010.01.013

Zichermann, G., \& Cunningham, C. (2011). Gamification by Design: Implementing Game Mechanics in Web and Mobile Apps. Sebastopol: O’Reilly Media. 